\title{
lon-selective electrode and anion gap range: What should the anion gap be?
}

\author{
This article was published in the following Dove Press journal: \\ International Journal of Nephrology and Renovascular Disease \\ 6 June 2013 \\ Number of times this article has been viewed
}

\author{
Seyed-Ali Sadjadi \\ Rendell Manalo \\ Navin Jaipaul \\ James McMillan \\ Jerry L Pettis Memorial Veterans \\ Medical Center, Loma Linda \\ University School of Medicine, \\ Loma Linda, CA, USA
}

Correspondence: Seyed-Ali Sadjadi Loma Linda VA Medical Center, Loma Linda, CA 92357, USA Fax+I 9095836090

Email sadjadia@yahoo.com
Background: Using flame photometry technique in the 1970s, the normal value of anion gap (AG) was determined to be $12 \pm 4 \mathrm{meq} / \mathrm{L}$. However, with introduction of the autoanalyzers using an ion-selective electrode (ISE), the anion gap value has fallen to lower levels.

Methods: A retrospective study of US veterans from a single medical center was performed to determine the value of the anion gap in subjects with normal renal function and normal serum albumin and in patients with lactic acidosis and end-stage renal disease on dialysis.

Results: In 409 patients with an estimated glomerular filtration rate $\geq 60 \mathrm{~mL} / \mathrm{min} / 1.73 \mathrm{~m}^{2}$ body surface area and serum albumin $\geq 4 \mathrm{~g} / \mathrm{dL}$, the mean AG was $7.2 \pm 2$ (range 3-11) meq/L. In 299 patients with lactic acidosis (lactate level $\geq 4 \mathrm{meq} / \mathrm{L}$ ) and 68 patients with endstage renal disease on dialysis, the mean AG was $12.5 \mathrm{meq} / \mathrm{L}$ and $12.4 \mathrm{meq} / \mathrm{L}$, respectively. A value $<2 \mathrm{meq} / \mathrm{L}$ should be considered a low anion gap and a possible clue to drug intoxication and paraproteinemic disorders.

Conclusion: With the advent of ISE for measurement of analytes, the value of the anion gap has fallen. Physicians need to be aware of the normal AG value in their respective institutions, and laboratories need to have an established value for AG based on the type of instrument they are using.

Keywords: acidosis, electrolytes, ESRD

\section{Introduction}

The anion gap (AG) represents the difference between the measured anion and cation concentrations in the serum, and is used by clinicians to diagnose acid base problems, especially in unsuspected cases of acidosis, alkalosis, drug poisoning, and disease states, particularly in emergency rooms and intensive care units, ${ }^{1-5}$ and as a quality control measure by laboratories. Although the concept of AG arose from the gamblegram described in 1939, it did not gain widespread recognition by physicians until the 1970s after the introduction of autoanalyzers and rapid availability of measuring multiple analytes. Originally, it was the difference between serum sodium and potassium on the one hand and chloride and bicarbonate concentrations on the other, but later on, it was simplified to the difference between sodium and the sum of chloride and bicarbonate concentrations, mainly because of the narrowness of the range of normal potassium concentration.

Prior to the introduction of the ion-selective electrode in the 1970s, flame photometry was the technique most often used to measure serum electrolytes. In a study of 1047 hospitalized patients, Wittle et al $^{6}$ reported a mean AG value of $12 \mathrm{meq} / \mathrm{L}$ with a $90 \%$ range of $8-17 \mathrm{meq} / \mathrm{L}$. This and other studies established the normal value 
for $\mathrm{AG}$ as $12 \pm 4 \mathrm{meq} / \mathrm{L}$. Compared with flame photometry, the ion-selective electrode (ISE) tends to give a higher concentration of serum chloride, so the AG value has fallen over time. We and others have shown that the actual value of the AG is much narrower than the currently published value $^{5-11,13,14}$ (Table 1). For this reason, we examined the AG value in a random sample of patients at a single United States Veterans Administration hospital.

\section{Materials and methods}

This study was a retrospective review of serum electrolytes and anion gap in 409 outpatients aged older than 18 years with an estimated glomerular filtration rate (GFR) of $>60 \mathrm{~mL} / 1.73 \mathrm{~m}^{2}$ body surface area and serum albumin $\geq 4 \mathrm{~g} / \mathrm{dL}$. We also reviewed serum electrolytes in 68 dialysis-dependent outpatients and 299 inpatients with lactic acidosis, defined as serum lactate level $\geq 4 \mathrm{meq} / \mathrm{L}$. The value of $4 \mathrm{meq} / \mathrm{L}$ was chosen to avoid including patients who had hyperlactatemia but not lactic acidosis. Serum electrolyte review was done on one random sample. Chemical analysis of serum was done using a Unicell DXC 800 autoanalyzer (Beckman Coulter, Inc., Fullerton, CA, USA) measuring sodium $(\mathrm{Na})$, potassium $(\mathrm{K})$, and chloride $(\mathrm{Cl})$ by indirect ionselective potentiometry. ${ }^{15}$ Serum albumin was measured by bromocresol purple methodology and serum creatinine by the alkaline picrate method. In our laboratories, serum chloride is not corrected for the excess value reported by ISE and the normal ranges for chloride and other electrolytes are: $\mathrm{Na}$ 136-144, K 3.6-5.1, Cl 101-111, and $\mathrm{CO}_{2}$ 22-32 meq/L.

\section{Results}

In the 409 patients with normal kidney function and serum albumin, the following was found: mean age \pm 1 standard deviation (SD) $52.8 \pm 15$ years, male/female ratio $93.4 \% / 6.6 \%$, $\mathrm{Na} 139.4 \pm 2.3 \mathrm{meq} / \mathrm{L}, \mathrm{K} 4.3 \pm 0.3 \mathrm{meq} / \mathrm{L}, \mathrm{Cl} 103.6 \pm 3.7 \mathrm{meq} / \mathrm{L}$, $\mathrm{CO}_{2}$ content $28.5 \pm 2.3 \mathrm{meq} / \mathrm{L}$, glucose $100 \pm 30.8 \mathrm{mg} / \mathrm{dL}$, calcium $9.5 \pm 0.3 \mathrm{mg} / \mathrm{dL}$, albumin $4.2 \pm 0.17 \mathrm{~g} / \mathrm{dL}$, blood urea nitrogen $13 \pm 13 \mathrm{mg} / \mathrm{dL}$, and creatinine $0.96 \pm 0.1 \mathrm{mg} / \mathrm{dL}$.
The mean anion gap in this group was $7.2 \pm 2$ (range 3.2-11.2) $\mathrm{meq} / \mathrm{L}$. In patients with lactic acidosis (serum lactate $\geq 4 \mathrm{meq} / \mathrm{L}$ ), mean age was $68 \pm 11.7$ years, with a male to female ratio of $96 \% / 4 \%$, serum Na $137.9 \pm 5.8 \mathrm{meq} / \mathrm{L}$, $\mathrm{K} 4.5 \pm 1 \mathrm{meq} / \mathrm{L}, \mathrm{Cl} 105 \pm 7.3 \mathrm{meq} / \mathrm{L}, \mathrm{CO}_{2} 19.9 \pm 6.0 \mathrm{meq} / \mathrm{L}$, glucose $161 \pm 89 \mathrm{mg} / \mathrm{dL}$, calcium $8.3 \pm 5.3 \mathrm{mg} / \mathrm{dL}$, albumin $2.4 \pm 0 \mathrm{~g} / \mathrm{dL}$, blood urea nitrogen $36 \pm 26.7 \mathrm{mg} / \mathrm{dL}$, creatinine $2.2 \pm 1.6 \mathrm{mg} / \mathrm{dL}$, and lactate $7.0 \pm 3.8 \mathrm{meq} / \mathrm{L}$. In this group, uncorrected for serum albumin, the mean anion gap was $12.5 \pm 8.0$ (range 2-32) meq/L. Uncorrected $\mathrm{AG}$ was $>15$ in $94(31 \%), 10-14$ in $124(41.4 \%)$, and $<10$ in $81(27 \%)$ patients. In patients with end-stage renal disease, the mean age was $65.4 \pm 9.6$ years, with a male/female ratio of $98.6 \% / 1.4 \%$, diabetes $77.9 \%$, hypertension $100 \%$, congestive heart failure $21 \%$, hepatitis $\mathrm{C}$ infection $11.7 \%, \mathrm{Na} 138.1 \pm 2.7 \mathrm{meq} / \mathrm{L}, \mathrm{K} 4.9 \pm 0.7 \mathrm{meq} / \mathrm{L}$, $\mathrm{Cl} 100.6 \pm 3.5 \mathrm{meq} / \mathrm{L}, \mathrm{CO}_{2} 25.1 \pm 2.9 \mathrm{meq} / \mathrm{L}$, glucose $144 \pm 65.3 \mathrm{mg} / \mathrm{dL}$, albumin $3.4 \pm 0.5 \mathrm{~g} / \mathrm{dL}$, blood urea nitrogen $56.5 \pm 20.5 \mathrm{mg} / \mathrm{dL}$, and creatinine $9.4 \pm 3.4 \mathrm{mg} / \mathrm{dL}$. In this group, mean AG was $12.4 \pm 3.2$ (range 6-26) meq/L (Tables 2 and 3). Uncorrected for serum albumin, AG was $>15$ in $21(31 \%), 10-14$ in $34(50 \%)$, and $<10 \mathrm{meq} / \mathrm{L}$ in $13(19 \%)$ patients. An AG <2, although rare, would be considered to be a low anion gap and a possible clue to disease entities like immunoglobulin G myeloma, and bromide or lithium intoxication. ${ }^{3,12}$

\section{Discussion}

Serum AG is a useful parameter for physicians to decipher acid base disorders and gain clues to the presence of unsuspected cases of alkalosis, acidosis, mixed acid base disorders, drug intoxication, and sometimes a clue to the presence of serious diseases. Other methods, like Stewart's method of measuring strong ion gap and strong ion difference, ${ }^{16-18}$ acid base nomograms, the slide rule, ${ }^{19}$ and base excess, are more cumbersome, complicated, and not readily accepted or used by physicians. Some physicians, particularly those in critical care, feel more comfortable with

Table I Studies describing anion gap values measured by an ion-selective electrode

\begin{tabular}{|c|c|c|c|c|}
\hline Author & $\begin{array}{l}\text { Year of } \\
\text { publication }\end{array}$ & Patients (n) & $\begin{array}{l}\text { Anion gap (mean } \pm \text { SD or } \\
\text { range), } \mathrm{meq} / \mathrm{L}\end{array}$ & Instrument used \\
\hline \multirow[t]{2}{*}{ Winter et al ${ }^{7}$} & 1990 & 29 healthy individuals & $5.9 \pm 1.2$ & ASTRA \\
\hline & & 120 blood donors & $6.0 \pm 1.4$ & \\
\hline Sadjadi $^{8}$ & 1995 & 222 & $6.6 \pm 2.0$ & Beckman \\
\hline Lolekha et $\mathrm{al}^{9}$ & 2001 & 124 & $5-12$ & Beckman Synchron CX5 \\
\hline Hassan et $\mathrm{al}^{10}$ & 2004 & 286 & $7.0 \pm 2.2$ & Beckman Synchron CX7 \\
\hline
\end{tabular}

Abbreviation: SD, standard deviation. 
Table 2 Patient demographics and laboratory data, shown as the mean \pm SD

\begin{tabular}{llll}
\hline Parameter & $\begin{array}{l}\text { Normal kidney } \\
\text { function }\end{array}$ & $\begin{array}{l}\text { Lactic } \\
\text { acidosis }\end{array}$ & $\begin{array}{l}\text { End-stage } \\
\text { renal disease }\end{array}$ \\
\hline $\mathrm{n}$ & 409 & 299 & 68 \\
Age, years & $52.8 \pm 15$ & $68 \pm 1 \mathrm{I} .7$ & $65.4 \pm 9.6$ \\
Male/female, \% & $93.4 / 6.6$ & $96 / 4.0$ & $98.6 / 1.4$ \\
Sodium, meq/L & $139.4 \pm 2.3$ & $137.9 \pm 5.8$ & $138.1 \pm 2.7$ \\
Potassium, meq/L & $4.3 \pm 0.3$ & $4.5 \pm 1.0$ & $4.9 \pm 0.7$ \\
Chloride, meq/L & $103.6 \pm 3.7$ & $105 \pm 7.3$ & $100.6 \pm 3.5$ \\
CO $_{2}, \mathrm{meq} / \mathrm{L}$ & $28.5 \pm 2.3$ & $19.9 \pm 6$ & $25.1 \pm 2.9$ \\
Glucose, $\mathrm{mg} / \mathrm{dL}$ & $100 \pm 30.8$ & $161 \pm 89$ & $144 \pm 65.3$ \\
Albumin g/dL & $4.3 \pm 0.2$ & $2.4 \pm 0$ & $3.4 \pm 0.5$ \\
BUN mg/dL & $13 \pm 13$ & $36 \pm 26.7$ & $56.5 \pm 20.5$ \\
Creatinine, $\mathrm{mg} / \mathrm{dL}$ & $0.96 \pm 0.1$ & $2.2 \pm 1.6$ & $9.4 \pm 3.5$ \\
\hline
\end{tabular}

Abbreviations: SD, standard deviation; BUN, blood urea nitrogen.

the Stuart formula and find it more helpful than the AG for detection of unmeasured anions.

However, the critical question is what is the normal mean and range for the $A G$. If the traditional value of $12 \pm 4 \mathrm{meq} / \mathrm{L}$ is used, clues to the presence of occult acid base problems will be missed, particularly in emergency rooms and intensive care units where time is of the essence for appropriate and efficient provision of medical care. Some research ${ }^{20}$ suggests that lower AG values have more sensitivity and specificity in the diagnosis of acid base problems, while others do not. ${ }^{21}$ This study, along with our previous study incorporating 631 patients, shows the actual value of the anion gap in people with normal kidney function to be $7.2 \pm 2$ (range $3-11) \mathrm{meq} / \mathrm{L}$, a value that is much lower than the usual value of $12 \pm 4 \mathrm{meq} / \mathrm{L}$ used currently. Some have argued that the problem caused by ISE can be solved if the laboratory corrects for the excess level of chloride. As pointed out by Winter et al, this requires frequent recalibration of the autoanalyzer by the laboratory, which is a cumbersome chore. ${ }^{7}$ Others advocate the use of a previous $A G$ value obtained while the patient was healthy as the basis for evaluation of AG. However, not every patient has a baseline AG value in his or her medical records and, most importantly, most laboratories do not

Table 3 Mean anion gap in patients with normal renal function, ESRD, and lactic acidosis

\begin{tabular}{lcl}
\hline Group & $\begin{array}{c}\text { AG, meq/L, } \\
\text { mean } \pm \text { SD }\end{array}$ & $\begin{array}{l}\text { AG range, meq/L } \\
\text { Uncorrected for } \\
\text { serum albumin }\end{array}$ \\
\hline eGFR $>60 \mathrm{~mL}$ per minute & $7.2 \pm 2.0$ & $3-11$ \\
ESRD & $12.4 \pm 3.2$ & $6-26$ \\
Lactic acidosis & $12.5 \pm 8.0$ & $2-32$ \\
\hline
\end{tabular}

Abbreviations: ESRD, end-stage renal disease; eGFR, estimated glomerular filtration rate; SD, standard deviation; $A G$, anion gap. have a normal AG range of their own and use the value recommended by the manufacturer of the instrument, which could vary from 10 to $20 \mathrm{meq} / \mathrm{L}$. For this reason, we believe the value of the AG needs to be lowered to $6-7 \mathrm{meq} / \mathrm{L}$ and that every laboratory should have an established value for AG. Clinicians should know which instrument is used in their laboratory and what is the normal AG value for their institution. In a review of 11,597 adults who participated in the National Health and Nutrition Examination Survey, conducted between 1999 and 2004 and using ISE, the mean value for AG was $12 \mathrm{meq} / \mathrm{L}$. However, it is not mentioned in this report if the value of chloride was corrected for ISE overestimation. $^{22}$

Why is the anion gap narrower? This relates to the fact that ISE gives a higher reading for chloride concentration compared with flame photometry and colorimetric techniques. In the study reported by Winter et al, ${ }^{7}$ the average serum chloride of 423 hospital employees measured using the ASTRA autoanalyzer (Beckman Coulter) was $107 \mathrm{meq} / \mathrm{L}$, while the reference serum chloride done using the Technicon instrument (Technicon Corporation, Tarrytown, NY, USA) in a previous study was $101 \mathrm{meq} / \mathrm{L}$. Lolekha et al point out that the lower AG value obtained with ISE analyzers compared with continuous flow analyzers is partly due to a greater loss of carbon dioxide with the latter types of instrument. ${ }^{9}$ The AG value is also dependent on the type of instrument used to measure its components. In the study reported by Roberts et al, the AG value was 5-10 with the Synchron CX3 analyzer (Beckman Coulter), 9-14 for the Hitachi 717 analyzer (Boehringer Mannheim, Mannheim, Germany), and 8-13 meq/L for the Vitros 950 analyzer (Johnson and Johnson, New Brunswick, NJ, USA). ${ }^{14}$

Another issue is the effect of serum albumin and other proteins on the anion gap. As calculated by Siggard-Anderson et al, albumin accounts for $73 \%$, globulins for $22 \%$, and phosphate for $5 \%$ of the buffer capacity of the blood..$^{23}$ This has traditionally required an upward adjustment of $2.0^{24}$ to $3 \mathrm{meq} / \mathrm{L}^{25-28}$ in the anion gap for every $\mathrm{g} / \mathrm{dL}$ decrease in serum albumin. In a study of 5328 patients, $70 \%$ of whom had normal serum albumin (3.5-4.7 g/dL), 21.7\% had hypoalbuminemia and $8 \%$ had hyperalbuminemia; the relationship between serum albumin and AG was linear, with a slope of $2.3 \mathrm{meq} / \mathrm{L}$ change in $\mathrm{AG}$ per $\mathrm{g} / \mathrm{dL}$ change in serum albumin concentration. ${ }^{29}$

Some authors have questioned the value of correcting AG for serum albumin while others have found it to be useful. In their study of intensive care patients, Dinh et al did not find much improvement in detecting hyperlactatemia using 
albumin corrected or uncorrected $\mathrm{AG} .{ }^{30} \mathrm{pH}$ also affects the charge on albumin but the effect is small, in the range of $0.5 \mathrm{meq} / \mathrm{L}$ per 0.1 unit change in $\mathrm{pH} .{ }^{31}$ As pointed out by Rastegar, in spite of its pitfalls, AG when corrected for serum albumin, is more sensitive than the Stuart method or base excess for delineation of acid base disorders. ${ }^{16}$

As expected, in our patients with lactic acidosis and endstage renal disease, AG was higher, with a mean value of $12.5 \mathrm{meq} / \mathrm{L}$. Because our study was retrospective and serum lactate levels and arterial blood gases were not routinely measured in all critically ill patients with lactic acidosis, we did not attempt to calculate the sensitivity and specificity of our findings. Some studies have reported sensitivity and specificity data based on retrospective observations. In our view, this is not appropriate and should be avoided. Certainly, no system is perfect, but we believe the time has come to change the AG value to a lower one to maintain its utility. ${ }^{32}$

Our study has some limitations. It was done in a single Veterans Administration medical center where the overwhelming majority of patients are elderly males, so our results may not be applicable to all patient groups, but the study also has some strengths. Combined with our previous research, ${ }^{8}$ it examines the value of the anion gap in almost 1000 patients using the current generation of autoanalyzers and compares the AG value in patients with normal kidney function, lactic acidosis, and end-stage renal disease.

\section{Disclosure}

The authors report no conflicts of interest in this work.

\section{References}

1. Kraut J, Medias N. Serum anion gap: its uses and limitations in clinical medicine. Clin J Am Soc Nephrol. 2007;2:162-174.

2. Van Hoeven KH, Joseph RE, Gaughan WJ, et al. The anion gap and routine serum protein measurements in monoclonal gammopathies. Clin J Am Soc Nephrol. 2011;6:2814-2821.

3. Vasuyattakul S, Lertpattanasuwan N, Vareesangthi K, et al. A negative anion gap as clue to diagnosis of bromide intoxication. Nephron. 1995;69: 311-313.

4. Gabow PA. Disorders associated with an altered anion gap. Kidney Int. 1983;27:472-485.

5. Fenves AZ, Kirkpatrick HM, Patel VV, Sweetman L, Emmett M. Increased anion gap metabolic acidosis as a result of 5-oxoproline (pyroglutamic acid): a role for acetaminophen. Clin J Am Soc Nephrol. 2006;1:441-447.

6. Wittle DL, Rodgers JL, Barrett DA. The anion gap: its use in quality control. Clin Chem. 1976;22:643-648.

7. Winter SD, Pearson JR, Gabow PA, Schultz AL, Lepoff RB. The fall of serum anion gap. Arch Intern Med. 1990;150:311-313.

8. Sadjadi SA. A new range for anion gap. Ann Intern Med. 1995;123:807.
9. Lolekha PH, Vanavanan S, Lolekha S. Update on value of anion gap in clinical diagnosis and laboratory evaluation. Clin Chim Acta. 2001;307: 133-136.

10. Hassan H, Joh JH, Bacon BR, Bastani B. Evaluation of serum anion gap in patients with liver cirrhosis of diverse etiologies. Mt Sinai J Med. 2004;71:281-284.

11. Jurado RL, del Rio C, Nassar G, Navarettes J, Pimental IL. Low anion gap. South Med J. 1998;91:624-629.

12. Kelleher SP, Raciti A, Arbeit LA. Reduced or absent serum AG as a marker of severe lithium carbonate intoxication. Arch Intern Med. 1986;146:1939-1940.

13. Lee S, Kang KP, Kang SK. Clinical usefulness of the serum anion gap. Electrolyte Blood Press. 2006;4:44-46.

14. Roberts WL, Johnson RD. Serum anion gap. Has the reference value really fallen. Arch Pathol Lab Med. 1997;121:568-572.

15. Fortgens P, Pillay TS. Pseudohyponatremia revisited, a modern day pitfall. Arch Pathol Lab Med. 2011;135:516-519.

16. Rastegar A. Clinical utility of Stewart's method in diagnosis and management of acid base disorders. Clin J Am Soc Nephrol. 2009;4: 1267-1274.

17. Lloyd P. Strong ion calculator - a practical bedside application of modern quantitative acid-base physiology. Crit Care Resusc. 2004;6: 285-294.

18. Kaplan LJ, Frangos S. Clinical review: acid-base abnormalities in the intensive care unit. Crit Care. 2005;9:198-203.

19. Di Iorio C, Rufolo L, Melillo EM, Granata A, Melillo G. The slide rule: a new method for the assessment of acid base equilibrium disorders. Minerva Anestesiol. 2007;73:339-342.

20. Singh RN, Singh NC, Hutchison J, Moses GC. Lower anion gap increases sensitivity in predicting elevated lactate levels. Clin Intensive Care. 1994;5:221-224.

21. Adams BD, Bonzani TA, Hunter CJ. The anion gap does not accurately screen for lactic acidosis in emergency department patients. Emerg Med. 2006;23:179-182.

22. Abramowitz M, Hostetter T, Melamed ML. The serum anion gap is altered in early kidney disease and associates with mortality. Kidney Int. 2012;82:701-709.

23. Siggard-Anderson O, Roth M, Strickland DAP. The buffer value of plasma, erythrocyte fluid and whole blood, In: Workshop $\mathrm{On} \mathrm{pH}$ and Blood Gases. Washington, DC: National Bureau of Standards; 1977.

24. Figge J, Jabor A, Kazda A, Fencl V. Anion gap and hypoalbuminemia. Crit Care Med. 1998;26:1807-1809.

25. Nicholson JP, Wolmarans MR, Park GF. The role of albumin in critical illness. Br J Anaesth. 2000;85:599-610.

26. Salem MM, Mujais SK. Gaps in the anion gap. Arch Intern Med. 1992;152:1625-1629.

27. Carvounis C, Feinfeld DA. A simple estimate of the effect of serum albumin level on the anion gap. Am J Nephrol. 2000;20:369-372.

28. Hatherill M, Waggie Z, Purves L, Reynolds L, Argent A. Correction of anion gap for albumin in order to detect occult tissue anions in shock. Arch Dis Child. 2002;87:526-529.

29. Feldman M, Soni N, Dickson B. Influence of hypoalbuminemia or hyperalbuminemia on the serum anion gap. J Lab Clin Med. 2005;146: 317-320.

30. Dinh $\mathrm{CH}, \mathrm{Ng} \mathrm{R}$, Grandinetti A, Joffe A, Chow DC. Correcting the anion gap for hypoalbuminemia does not improve detection of hyperlactatemia. Emerg Med J. 2006;23:627-629.

31. Paulson WD. Effect of acute $\mathrm{pH}$ change on serum anion gap. JAm Soc Nephrol. 1996;7:357-363.

32. Lolekha PH, Vanavanan S, Teerakanjana N, Chaichanajaremkul U. Reference ranges of electrolytes and anion gap on the Beckman E4A, Beckman Synchron CX5, Nova CRT, and Nova Stat Profile Ultra. Clin Chem Acta. 2001;307:87-93. 


\section{Publish your work in this journal}

The International Journal of Nephrology and Renovascular Disease is an international, peer-reviewed open-access journal focusing on the pathophysiology of the kidney and vascular supply. Epidemiology, screening, diagnosis, and treatment interventions are covered as well as basic science, biochemical and immunological studies. The journal welcomes original research, clinical studies, reviews \& evaluations, expert opinion and commentary, case reports and extended reports. The manuscript management system is completely online and includes a very quick and fair peerreview system, which is all easy to use. Visit http://www.dovepress.com/ testimonials.php to read real quotes from published authors

Submit your manuscript here: http://www.dovepress.com/international-journal-of-nephrology-and-renovascular-disease-journal 